\title{
Editorial
}

\section{O SUS precisa de Mais Médicos e de Muito Mais!}

s manifestaçóes de rua e as consequentes respostas governamentais têm gera-
do um intenso debate na sociedade sobre as políticas públicas, entre elas, as de saúde. Para o Centro Brasileiro de Estudos de Saúde (CEBES), o momento é de celebração do aperfeiçoamento e de aprofundamento da democracia brasileira. Nossa contribuiçẫo nesse debate expõe nossas posiçôes e propostas para o setor da saúde brasileiro, cotejadas ao Programa Mais Médicos, que o governo apresenta como estratégia para atendimento das demandas populares.

É imprescindível reconhecer que a assistência à saúde é dependente dos trabalhadores da saúde e de sua capacidade de produzir o cuidado. Em uma época em que se supervalorizam as máquinas, os exames e a tecnologia, é necessário reafirmar que saúde se faz com gente. Todas as profissōes da saúde são fundamentais para uma assistência integral, ou seja, é a equipe de saúde que será capaz de atender e resolver todos os problemas apresentados pela população.

A suficiência quantitativa das equipes de saúde, quando bem distribuídas, permitirá o atendimento universal da população residente em todo o território, efetivando o direito constitucional dos brasileiros.

Entretanto, é consenso entre os gestores de todas as esferas do SUS que, entre todas as categorias profissionais da saúde, os médicos são os profissionais mais difíceis de prover nos serviços públicos de saúde.

A população também reconhece esse problema quando aponta, como mostrou recente pesquisa do IPEA, que o principal problema do SUS é a falta de médicos. Mesmo discordando dessa assertiva, que localiza a falta de médicos como o principal problema da saúde, o CEBES não pode deixar de reconhecer o que mostram diversos estudos: que faltam médicos no Brasil, e que essa falta ocorre, principalmente, no SUS. Não concordando com a argumentação das entidades médicas, que insistem na suficiência de médicos, o CEBES diagnostica a deficiência e a má distribuição de médicos como um problema grave.

Por outro lado, ressaltamos que o principal problema do SUS não é a falta de médicos. Na verdade, esse é mais um dos sintomas do descaso crônico na implantação do projeto SUS, relegado pelos sucessivos governos pós-constitucionais ao destino de ser um sistema de baixa qualidade para atendimento da populaçáo pobre. 
É preciso reafirmar que o principal problema do SUS é a subordinação do setor da saúde à lógica de mercado, que se expande sufocando o direito social previsto na Constituição. Essa lógica de mercado trata a saúde - assim como a doença - como mercadoria, e o crescimento desse mercado, como vem ocorrendo no país, faz com que a saúde se distancie dos princípios que orientam o SUS enquanto expressão da saúde como um direito de cidadania.

É preciso analisar as razóes pelas quais os médicos não se vinculam ao SUS e não ocupam o vasto território vazio desses profissionais. Nesse sentido, refutamos o argumento de que são apenas as más condições de estrutura e trabalho que explicam a ausência de médicos no SUS. Isso só poderia ser verdade se existisse um contingente de médicos desempregados por recusa de condiçóes insuficientes, o que não existe. Ao contrário, praticamente todos os médicos brasileiros possuem um ou mais empregos, como evidenciam os estudos. Outra pesquisa do IPEA, ainda mais recente, mostra que, em média, os médicos brasileiros trabalham 42 horas por semana, e ganham, aproximadamente, $\mathrm{R} \$ 8.500,00$ por mês, o que os coloca no topo de rendimentos entre as profissões de nível superior.

O Brasil vive um 'boom’ de crescimento do mercado da saúde, e hoje já conta com a presença do grande capital internacional e dos fundos de investimentos. Esse boom expressa a política concreta, que vem sendo praticada, de promover e conduzir o setor da saúde ao mercado, e se aproveita do resultado da política de inclusão social, pautada pela expansão do consumo, tônica da política econômica dos últimos anos.

Essa política de ampliação do consumo, associada à omissão, seja por falta de coragem ou de tendência na correlação de forças, que caracteriza os últimos governos federais, que não enfrentam os interesses dos complexos econômicos da saúde (indústria farmacêutica, de equipamentos, planos e seguros privados de saúde, prestadores privados de serviços) e seguem promovendo o crônico subfinanciamento do SUS, criando as condições ideais para a expansão do mercado da saúde. Essa é a principal razão que proporciona a concentração de médicos no setor privado e sua consequente escassez no setor público, modelo que saqueia o SUS e gera outras graves distorções na saúde brasileira.

As multidóes de brasileiros que foram às ruas em todas as cidades, exigindo saúde e serviços públicos de qualidade, para nós, são a expressão de ser possível iniciar novos pactos sociais, dentro e fora do setor Saúde, criando efetivas condiçóes para uma mudança nessa correlação de forças, que privilegie o interesse público ante os interesses econômicos.

Nesse contexto de situar o direito à saúde no centro do projeto político de desenvolvimento social e econômico do país, o CEBES chama a atenção para o fato de que as medidas que compóem o Programa Mais Médicos são necessárias e 
louváveis, porém, insuficientes para o setor, que necessita, urgentemente, de outras medidas estruturantes de curto, médio e longo prazos. Com essas referências para o entendimento da crise setorial, expressamos nossa preocupação e apresentamos propostas relativas ao Pacto pela Saúde, formulado pelo Governo Federal:

- Mediante a injusta falta de assistência médica que acomete a população e a dificuldade dos gestores em contratar profissionais médicos, é muito bem-vinda a atração de profissionais médicos estrangeiros ao país. Entretanto, tal medida deve ter caráter emergencial e focalizado para garantir o clamor do povo brasileiro, que expressou isso nas ruas, denunciando que parcelas significativas da população não tenham garantido seu direito constitucional à assistência médica. Simultaneamente, deverão ser adotadas medidas estruturantes para o problema;

- Mesmo sem tangenciar o grave problema do subfinanciamento setorial, o anúncio de investimentos na infraestrutura das unidades de saúde, especialmente na Rede de Atenção Básica, constitui uma medida importante e necessária, que respeita os profissionais de saúde e, principalmente, os usuários do SUS. A medida adequada e de longo prazo é garantir financiamento para investimentos permanentes no sistema;

- É preciso aprofundar as mudanças curriculares na formação médica, para além da ampliação do tempo do curso. Sob tal perspectiva, o Ministério da Saúde, como gestor nacional do Sistema Único de Saúde, deve fazer valer sua atribuição constitucional de "ordenar a formação de recursos humanos na área de saúde", expressa no inciso III do artigo 200 da Carta Magna;

- É preciso que as universidades tenham como missão primeira formar os profissionais de saúde com o perfil necessário para as necessidades da população brasileira, ou seja, o trabalho no SUS. Para isso, é fundamental que o ensino seja totalmente integrado à Rede de Atenção à Saúde, e que sejam rompidos os entraves que apartam os Hospitais Universitários do SUS;

- É igualmente necessário que a expansão das vagas e dos cursos de graduação em medicina seja feita essencialmente via universidades públicas, e nas localidades que mais necessitam de médicos. É preciso ampliar acesso e interiorizar as escolas de medicina, e isso deve ser feito pela expansão da rede de Universidades Federais; 
- Tẫo importante quanto formar médicos com perfil ético e humano para trabalhar no SUS é formar os especialistas necessários para garantir a integralidade da assistência. Universalizar a Residência Médica e torná-la obrigatória, garantindo vagas a todos os egressos de acordo com as necessidades do Sistema Único de Saúde, é uma necessidade;

- Merece nosso apoio a contratação estratégica de médicos brasileiros, por parte do governo federal, para atuarem nos municípios e nas áreas de difícil provimento, onde a ausência desses profissionais é mais sentida pela população. Mas são necessárias mudanças na Lei de Responsabilidade Fiscal, que limita a capacidade dos municípios e estados de contratação de profissionais de saúde, que, preferencialmente, devem estar vinculados institucionalmente aos municípios;

- Imediatamente, deve ser criado e implantado o Plano Nacional de Cargos, Carreiras e Salários para os trabalhadores do SUS, conforme foi apontado na última Conferência Nacional de Saúde. O CEBES defende a criação imediata da carreira nacional nos moldes definidos pela Mesa de Negociação Permanente do SUS.

É fundamental que o governo federal saiba aproveitar esse momento em que a sociedade brasileira reivindica serviços públicos de saúde com garantia de acesso e qualidade, e corrija o erro que foi a regulamentação da Emenda Constitucional 29 , sem a vinculação do percentual de $10 \%$ da Receita Corrente Bruta da União para a Saúde.

Com a retirada dos incentivos e as renúncias fiscais aos planos e seguros privados de saúde, e com o incremento de recursos advindos dos royalties do Pré-Sal e da Taxação de Grandes Fortunas, é perfeitamente possível garantir esse patamar mínimo de investimento na saúde dos brasileiros, sem que isso acarrete desequilíbrio fiscal.

Temos convicção de que, com o investimento adequado e com a coragem necessária para enfrentar os interesses econômicos que incidem sobre o setor saúde, é possível e necessário consolidar o direito cidadão à saúde e o Sistema Único de Saúde, como demanda o povo brasileiro. O SUS precisa de Mais Médicos e de Muito Mais... 